\title{
SISTEM PAKAR PEMENUHAN GIZI BAGI PENDERITA DIABETES MELITUS TIPE 2 MENGGUNAKAN METODE FORWARD CHAINING BERBASIS ANDROID
}

\author{
Paryanta $^{1}$, Richard Saputro ${ }^{2}$ \\ 1 Teknik Komputer, STMIK AUB SURAKARTA \\ 2 Sistem Informasi, STMIK AUB SURAKARTA \\ Email: ${ }^{1}$ paryanta@stmik-aub.ac.id, ${ }^{2}$ elricouno1391@gmail.com
}

\begin{abstract}
Abstrak
Peran teknologi informasi dibidang kesehatan saat ini sangatlah besar, ini ditandai dengan pembuatan dan pengembangan sistem informasi atau aplikasi berbasis android yang dapat membantu menyelesaikan pekerjaan dalam segala bidang. Di bidang kesehatan penyakit Diabetes Mellitus Tipe 2 adalah salah satu klasifikasi penyakit Diabetes Mellitus (DM) dimana ada resistensi dari sel otot maupun sel jaringan lemak untuk dimasuki gula darah. Penderita DM di Indonesia menempati urutan ke-7 dunia dengan 8,5 juta jiwa dan urutan ke-6 untuk kasus kematian, dengan 90-95\% adalah jenis DM tipe 2. Tujuan penelitian ini adalah merancang dan membangun Sistem Pakar Pemenuhan Gizi Bagi Penderita Diabetes Mellitus Tipe 2 Menggunakan Metode Forward Chaining Berbasis Android berdasarkan berat badan, tinggi badan, jenis kelamin, pekerjaan dan golongan darah. Dalam membangun sistem tersebut metode pendekatan yang digunakan adalah metode perancangan sistem menggunakan pemodelan UML (Unified Modeling Language) dengan komponen yang digunakan yaitu usecase diagram, activity diagram, sequence diagram, dan desain interface, menggunakan bahasa pemrograman Java dengan Apache Cordova dan database menggunakan MySQL. Hasil dari penelitian ini adalah membuat Sistem Pakar Pemenuhan Gizi Bagi Penderita Diabetes Mellitus Tipe 2 Menggunakan Metode Forward Chaining Berbasis Android yang dapat membantu mempermudah masyarakat penderita diabetes mellitus tipe 2 dengan cukup menggunakan smartphone yang memiliki sistem operasi android untuk pemenuhan gizi tanpa harus mengeluarkan banyak biaya dan waktu dalam hal konsultasi dengan ahli gizi.
\end{abstract}

Kata Kunci: Sistem pakar, Diabates Mellitus, Pemenuhan Gizi

\begin{abstract}
The role of information technology in the health sector today is very large, this is marked by the creation and development of information systems or android-based applications that can help complete work in all fields. In the health sector, Type 2 Diabetes Mellitus is one of the classifications of Diabetes Mellitus (DM) where there is resistance from muscle cells and fat tissue cells to enter blood sugar. DM sufferers in Indonesia ranks 7th in the world with 8.5 million people and 6th for cases of death, with 90-95\% being type 2 DM. The purpose of this study was to design and build a Nutrition Fulfillment Expert System for Diabetics. Mellitus Type 2 Using Android-Based Forward Chaining Method based on weight, height, gender, occupation and blood type. In building the system the approach method used is the system design method using UML (Unified Modeling Language) modeling with the components used, namely use case diagrams, activity diagrams, sequence diagrams, and interface designs, using the Java programming language with Apache Cordova and database using MySQL. The result of this research is to create a Nutrition Fulfillment Expert System for Patients with Type 2 Diabetes Mellitus Using the Android-Based Forward Chaining Method which can help make it easier for people with type 2 diabetes mellitus by simply using a smartphone that has an Android operating system to fulfill nutrition without having to spend a lot of money and time in terms of consultation with a nutritionist.
\end{abstract}

Keywords: Expert system, Diabetes Mellitus, Nutrition Fulfillment

\section{PENDAHULUAN}

Bidang kesehatan merupakan bagian dari bidang-bidang lain yang memanfaatkan teknologi informasi dan komunikasi, salah satunya yang digunakan untuk menentukan jumlah kalori diet dan pemenuhan gizi 
bagi penderita penyakit Diabetes Mellitus (DM). Penyakit Tidak Menular (PTM), termasuk Diabetes saat ini telah menjadi ancaman serius kesehatan global. Diabetes Mellitus yang memprihatinkan dan merupakan salah satu penyakit kronis di mata pemerintah Indonesia maupun dunia. Fakta dan kondisi yang ada saat ini di lingkungan mengenai penyakit Diabetes Mellitus (Almatsier, 2007); Diabetes adalah penyakit yang bisa menyebabkan komplikasi serius seperti jantung, stroke, kebutaan, gagal ginjal, dan amputasi kaki. Tahun 2013 sebanyak 6,9\% penduduk Indonesia dan melonjak pesat menjadi 8,5\% pada tahun 2018, dan diperkirakan akan menimpa 21 juta penduduk Indonesia di tahun 2030 (WHO, 2019). Menurut International Diabetic Federation (IDF) penderita DM di Indonesia menempati urutan ke-7 di seluruh dunia dengan 8,5 juta jiwa dan urutan ke-6 untuk kasus kematian sebelum berusia 70 tahun akibat DM (IDF, 2015). 90-95\% dari kasus Diabetes adalah Diabetes Tipe 2 yang sebagian besar dapat dicegah karena disebabkan oleh gaya hidup yang tidak sehat. berdasarkan data dari Dinas Kesehatan Surakarta, menyatakan Kota Surakarta memiliki prevalensi DM tipe 2 yang mengalami perubahan dalam 5 tahun terakhir. Peningkatan DM tipe 2 atau non dependent DM dari 5.223 kasus pada tahun 2016 mencapai 6.579 kasus pada tahun 2017 (Dinkes Surakarta, 2017).

Beberapa tahun belakangan masyarakat meneluhkan belum adanya solusi bagi penderita Diabetes Mellitus. Hal-hal yang membuat masyarakat penderita DM mengeluh dan terbebani adalah tingginya biaya konsultasi pemenuhan gizi, interval konsultasi yang tidak menentu dan waktu konsultasi yang menyita waktu sedangkan mereka harus bekerja untuk mencari penghasilan. Oleh karena itu dalam memecahkan permasalahan ini di perlukan media atau sarana yang membutuhkan biaya terjangkau, interval konsultasi yang bisa di atur sendiri dan waktu yang fleksibel tanpa harus mengorbankan pekerjaan para penderita DM.

Pemenuhan gizi bagi penderita diabetes melitus merupakan hal yang penting untuk membantu penderita dalam mengontrol kadar gula dalam darahnya dan memulihkan keadaan fisiknya layaknya orang sehat. Berdasarkan hasil peneltian dari beberapa peneliti menyatakan bahwa penyakit DM salah satu penyakit yang tidak dapat disembuhkan secara keseluruhan. Menurut Irma Ristiani, S.Gz. salah satu cara pengobatan penyakit diabetes adalah dengan mengontrol gizi makanan yang dikonsumsi penderit, gizi makanan yang dikonsumsi oleh penderita diabetes harus disesuaikan dengan jumlah kalori, jadwal makan, dan jenis makanan dengan kondisi tubuh penderita. Dengan pengaturan pola makan yang baik dan bergizi, perkembangan Penggunaan teknologi Expert system (ES) dalam kehidupan sehari-hari telah banyak di implementasikan untuk kepentingan komersial, salah satunya yaitu di bidang kesehatan seperti GoodDocter, HaloDokter ataupun konsultasi kesehatan online yang memanfaatkan teknologi ES sebagai pemandu pemecahan masalah dan mendapatkan solusi yang konkrit. penyakit diabetes dapat dihambat.

Dalam peneltian dalam mengembankan sistem pakar ini menggunakan Forward Chaining. Forward chaining melakukan pemrosesan berawal dari sekumpulan data untuk kemudian dilakukan inferensi sesuai dengan aturan yang diterapkan hingga ditemukan kesimpulan yang optimal (Candra, 2014). Ahli gizi akan memberikan rule-rule atau aturan dalam menentukan menu makanan sehat dan penderita diabetes akan mengisi data-data mengenai kondisi tubuhnya yaitu berat badan, jenis kelamin, umur, pekerjaan, dan golongan darah. Dengan menggunakan forward chaining data kondisi tubuh tersebut akan menentukan jumlah kalori yang dibutuhkan penderita. Data-data seperti jumlah kalori, kadar gula darah serta tekanan darah dapat berpengaruh pada makanan dikonsumsi oleh penderita. Sistem pakar ini akan di-install pada perangkat smartphone yang memiliki sistem operasi android. Program bantu dengan teknologi ES di bidang kesehatan ini berwujud aplikasi berbasis android yang akan menampilkan petunjuk untuk menentukan jumlah kalori diet dan pemenuhan gizi bagi penderita diabetes berdasarkan berat badan, umur, jenis kelamin dan golongan darah.

\section{METODE PENELITIAN}

Dalam pengambangan sistem pakar ini, dalam menganalisa sistem menggunakan metode PIECES, pengembangan sistem menggunakan metode Waterfall, sedangkan perancangan sistem menggunakan Unifield Modeling Languade (UML) terdiri dari Usecase Diagram, Class Diagram, Squence Diagram, Activity Diagram. Rekayasa sistem yang dirancang menggunakan metode Forward Chaining yaitu merancang dan membangun sistem pakar yang dapat membantu pengguna melakukan konsultasi dan mendapatkan informasi jumlah kalori, menu makanan bergizi dan pola hidup sehat yang tepat dan sesuai dengan kondisi tubuh penderita diabetes mellitus tipe 2. Data diambil dari responden dan ahli gizi yang melakukan konsultasi tentang pola hidup sehat bagi penderita Diabetes Mellitus tipe 2.

\subsection{Jenis Dan Sumber Data}

Data yang digunakan dalam penelitian ini adalah primer dan sekunder.

a. Data Primer

Data primer adalah data yang diperoleh dari sumber secara langsung yaitu orang dijadikan obyek sumber utama untuk menggali informasi yang dibutuhkan dalam penelitianini. Sumber data primer dari penelitian yaitu ahli gizi bernama Irma Ristiani, S.Gz. Bekerja di RSUD Moewardi Surakarta. 


\section{b. Data Sekunder}

Data sekunder merupakan data pendukung untuk keperluan dalam melakukan penelitian yang diperoleh secara tidak langsung, data yang diperolehnya dari perpustakaan, artikel Jurnal komputer berbasis android (apache cordova atau phonegap), literatur - literature tentang android, penyakit Diabetes Mellitus, internet.

\subsection{Metode Pengumpulan Data}

a. Observasi

Penulis melakukan observasi untuk mengumpulkan data dengan melakukan pengamatan langsung dari pakar gizi yang memiliki banyak pengalaman dalam menangani kasus pasien penderita Diabetes mellitus Tipe 2.

b. Wawancara

Penulis melakukan wawancara dengan pakar secara intens dan detail untuk mendapatkan data-data yang dibutuhkan seperti definisi Diabetes Mellitus Tipe 2, cara mengobati, merawat, menjaga pola makan dan apa saja menu makanan yang dibutuhkan untuk pemenuhan gizi.

c. Metode Pustaka

Penulis mencari referensi dari buku-buku baik yang ada di perpustakaan atau jurnal tentang ilmu sistem informasi, sistem operasi android, apache cordova dan diabetes mellitus sebagai bahan referensi dalam pembuatan laporan.

\subsection{Metode Pengembangan Sistem}

Dalam pengembangan sistem pakar ini, penulis menggunakan metode Waterfall. Metode Waterfall adalah suatu proses pengembangan perangkat lunak (software) dengan model berurutan dari atas mengajlir menuju ke bawah atau seperti air terjun yang melewati fase-fase proses perencanaan, pemodelan, konstruksi, pengujian dan implementasi. Berikut adalah fase-fase pengembangan sofware secara linear yang dapat dilihat pada gambar 1. (Pressman, 2001).

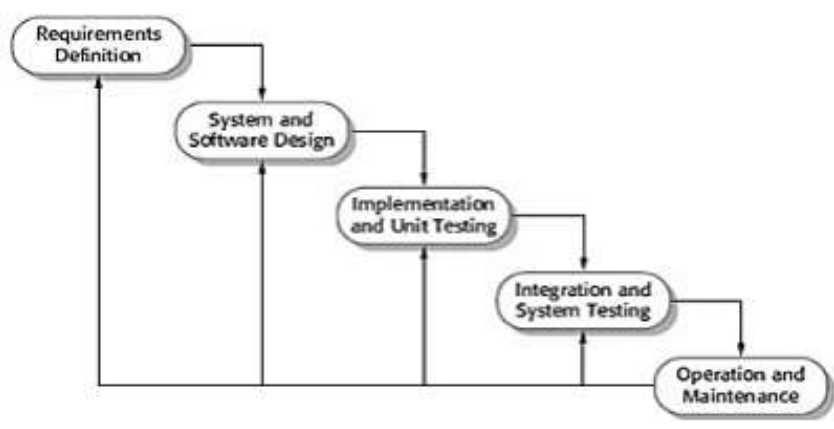

Gambar 1 Metode Waterfall . (Sumber: Pressman, 2001)

2.4 Metode Forward Chaining dalam penerapan Perhitungan Asupan Kalori Dalam Menu Makanan

a. Berat Badan

Dalam menentukan takaran menu makanan yang baik penderita diabetes dapat digolongan menjadi beberapa menu makanan yang dikonsumsi, yaitu jumlah kalori. Dimana jumlah kalori ditentukan berdasarkan Indeks Massa Tubuh (IMT), seperti pada Tabel 1

Tabel 1 Klasifikasi Nilai IMT bagi penderita diabetes.

\begin{tabular}{ccc}
\hline IMT & $\begin{array}{c}\text { Menu sehat diabetes } \\
\text { dengan kalori }\end{array}$ & Kategori berat badan \\
\hline$<18,5$ & $2100 \mathrm{kkal}$ & Kurang \\
$18,5-22,9$ & $2500 \mathrm{kkal}$ & Normal \\
$23-24,9$ & $2000 \mathrm{kkal}$ & Obesitas Ringan \\
$25-29,9$ & $1500 \mathrm{kkal}$ & Obesitas Sedang \\
$>=30$ & $1000 \mathrm{kkal}$ & Obesitas Berat \\
\hline
\end{tabular}

Sumber : (Lusiana dan Qoiriah, 2014)

Perhitungan IMT dengan rumus sebagai berikut:

$$
\mathrm{MMT}=\frac{\mathrm{BB}(\mathrm{Kg})}{\mathrm{TB}(\mathrm{m}) \times 100} \times 2
$$


Contoh :

Sumber : (Lusiana dan Qoiriah, 2014)

Berat Badan $=60 \mathrm{~kg}$ Tinggi Badan $=170 \mathrm{~cm}$

IMT $=60 /(170 / 100) 2=17,64$.

Sesuai dengan tabel 1 dapat dilihat bahwa IMT =17,64 bagi penderita diabetes adalah berat badan kurang.

b. Jenis Kelamin

Rumus Brocca yang dikutip dari tulisan Steven B.Halls (2005) adalah :

$$
\begin{aligned}
& \text { Wanita: } \\
& \text { Berat Badan Ideal }(\mathrm{kg})=\text { Tinggi Badan }(\mathrm{cm})-100 \pm 15 \% \\
& \text { Pria : } \\
& \text { Berat Badan Ideal }(\mathrm{kal}=\text { Tinaai Badan }(\mathrm{cm})-100 \pm 10 \%
\end{aligned}
$$

Sedangkan Rumus Brocca untuk menghitung Berat Badan Ideal (BBI) yang dikutip dari publikasi di website Depkes RI adalah :

$$
\mathrm{BBI}=90 \% \text { (Tinggi Badan } \mathrm{cm}-100) \times 1 \mathrm{~kg}
$$

Untuk pria dengan tinggi $<160 \mathrm{~cm}$ dan wanita $<150 \mathrm{~cm}$, menggunakan rumus :

$$
\mathrm{BBI}=(\text { Tinggi Badan } \mathrm{cm}-100) \times 1 \mathrm{~kg}
$$

Menurut perhitungan rumus PERKENI atau Perkumpulan Endokrinologi Indonesia (Wahyuningsih, 2013), rumus perhitungan sesuai dengan jenis kelamin yang di hitung dari berat badan ideal adalah :

Laki - laki $=\mathrm{BBI}(\mathrm{kg}) \times 30$ kalori

Perempuan $=\mathrm{BBI}(\mathrm{kg}) \times 25$ kalori

c. Umur

Menurut Harris dan Benedict angka Metabolisme Basal (AMB) adalah jumlah energi yang dibutuhkan tubuh hanya untuk hidup, tanpa melakukan kegiatan apa-apa. AMB akan semakin berkurang seiring dengan usia kita. Berikut rumus untuk menghitung AMB orang normal :

AMB laki-laki $=$

$66,4730+(13,7516 \times \mathrm{BB} \mathrm{kg})+(5,0033 \times \mathrm{TB} \mathrm{cm}-(6,7550 \times \mathrm{usia})$

AMB perempuan $=$

$655,0955+(9,5634 \times \mathrm{BB} \mathrm{kg})+(1,8496 \times \mathrm{TB} \mathrm{cm})-(4,6756 \times \mathrm{usia})$

Keterangan :

AMB : Angka Metabolisme Basal

BB : : Berat Badan $(\mathrm{kg})$

TB $\quad$ : Tinggi Badan $(\mathrm{cm})$

Usia : Usia Sekarang (th)

Kemudian Perhitungan kebutuhan kalori berdasarkan umur bagi penderita DM yang dilakukan menurut perhitungan rumus PERKENI (Perkumpulan Endokrinologi Indonesia). (Wahyuningsih, 2013) adalah:

Umur $40-59$ tahun $=$ AMB $-5 \%$

Umur $60-69$ tahun $=\mathrm{AMB}-10 \%$

Umur $\geq 70$ tahun $=$ AMB $-20 \%$

d. Pekerjaan

Dihitung sesuai dengan pekerjaan yang dilakukan. Perhitungan menurut rumus PERKENI atau Perkumpulan Endokrinologi Indonesi (Wahyuningsih, 2013) pada Keadaan Istirahat $=+10 \% \mathrm{x}$ kebutuhan basal (AMB) Aktivitas Ringan $=+20 \% \times$ kebutuhan basal $($ AMB) Aktivitas Sedang $=+30 \%$ $x$ kebutuhan basal (AMB) Aktivitas Berat $=+50 \% \times$ kebutuhan basal $(A M B)$ Aktivitas Sangat Berat $=$ 
$+50 \% \times$ kebutuhan basal (AMB) Pengelompokan kategori masing-masing aktivitas dapat dilihat pada Tabel 2.

Tabel 2 Kategori Aktivitas dalam Pekerjaan

\begin{tabular}{|c|c|}
\hline Kategori & Aktivitas \\
\hline Ringan & $\begin{array}{l}\text { Pegawai toko, Guru, Pegawai kantor, } \\
\text { lbu rumah tangga dan sekretaris. }\end{array}$ \\
\hline Sedang & $\begin{array}{l}\text { Mahasiswa dan Pegawai Industri } \\
\text { Ringan (konveksi dan Industri RT). }\end{array}$ \\
\hline Berat & Buruh, Penari, Pelaut, Atlet \\
\hline Sanga & $\begin{array}{l}\text { Tukang Becak, Pandai besi, Tukang } \\
\text { Bangunan }\end{array}$ \\
\hline
\end{tabular}

e. Golongan Darah

Menurut Gusti dan Aldi (2010), Golongan darah adalah ciri khusus darah dari suatu individu karena adanya perbedaan jenis karbohidrat dan protein pada permukaan membrane sel darah merah. Dua jenis penggolongan darah yang paling penting adalah penggolongan $\mathrm{ABO}$ dan Rhesus.

Diet golongan darah adalah pola dan aturan makan yang dirancang oleh Dr. Peter J. D'Adamo. Keberhasilan diet golongan darah ini dititikberatkan pada kondisi dan kebutuhan tubuh pelakunya dan bertujuan untuk mencapai kesehatan tubuh. Diet golongan darah yang diteliti oleh D'Adamo menujukkan efek fisiologis dari lektin yang masuk ke dalam tubuh. Lektin adalah protein yang umumnya terdapat pada makanan. Setiap jenis makanan dapat mempengaruhi metabolisme dan komposisi darah dalam tubuh. Keduanya mempengaruhi keseimbangan daya tahan tubuh (Savitri, 2016).

\subsection{Perancangan Sistem Pakar}

\section{a. Usecase Diagram}

Usecase Diagram menggambarkan interaksi antara aktor dan sistem pakar, terdapat tiga aktor yaitu:

1) Pengelola aplikasi adalah aktor yang mengolah data dan menerima laporan dari aplikasi serta pengelola aplikasi yang berhak meng-up grade aplikasi.

2) Pakar Gizi adalah yang memiliki tugas untuk menjawab konsultasi online dengan pengguna dan mengontrol validasi data hasil sistem pakar sebelum di informasikan kepada pengguna.

3) User atau Pengguna Aplikasi adalah Masyarakat khususnya warga kota Surakarta yang memiliki penyakit Diabetes Mellitus Tipe 2.

Usecase Diagram Aplikasi Sistem Pakar Pemenuhan Gizi Bagi Penderita Diabetes Mellitus Tipe 2 Menggunakan Metode Forward Chaining Berbasis Android dapat dilihat di gambar 2.

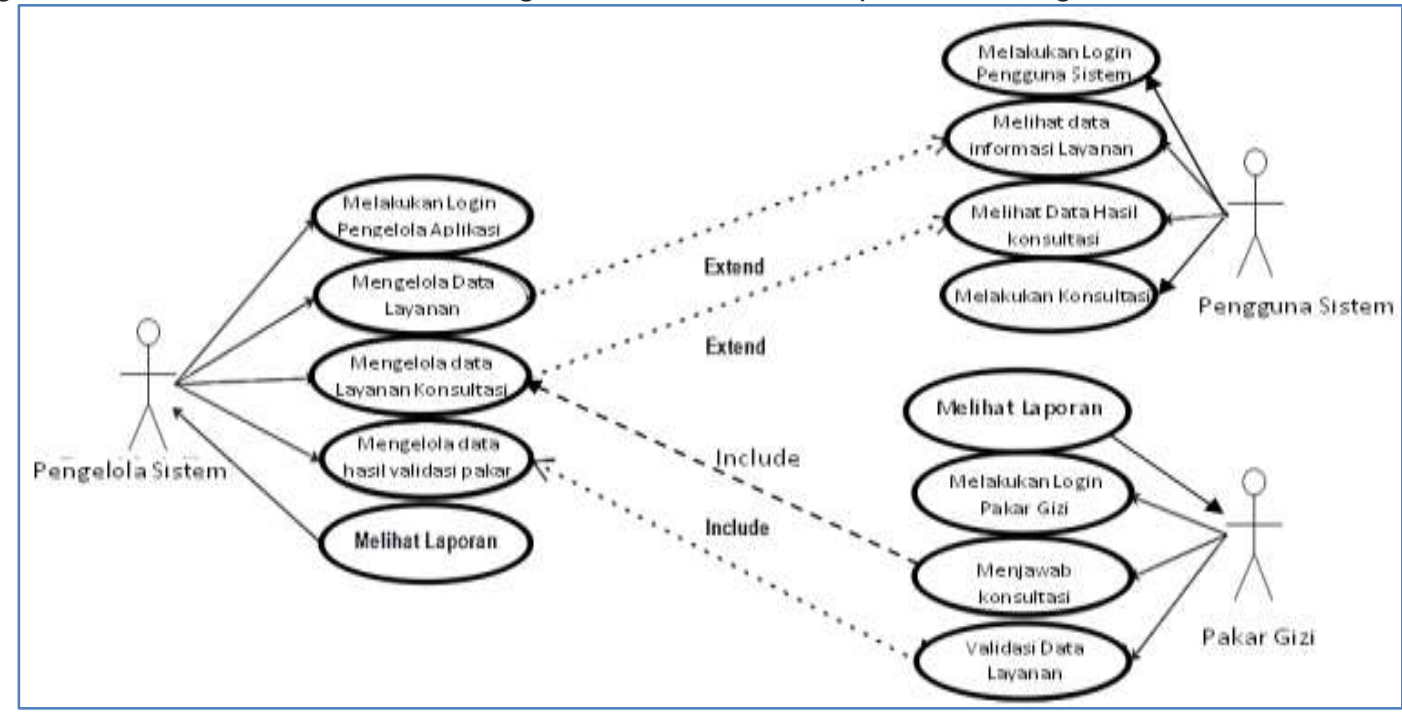

Gambar 2 Use Case Diagram Sistem Pakar Pemenuhan Gizi Bagi Penderita DM Tipe 2

\section{b. Activity Diagram}

Activity Diagram menggambarkan aliran kegiatan yang dilakukan oleh aktor berdasarkan tugas dan fungsi dari actor dalam sebuah interaksi. 


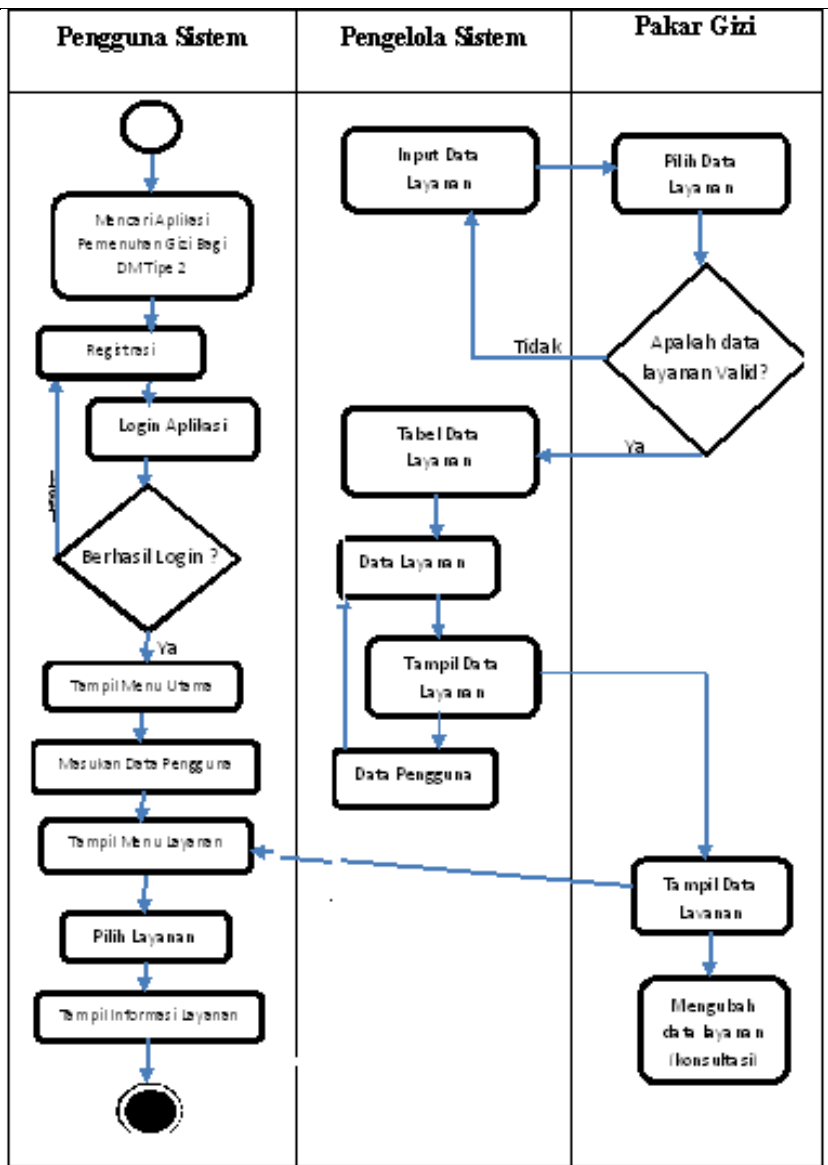

Gambar 3 Activity Diagram Sistem Pakar Pemenuhan Gizi Bagi Penderita DM Tipe 2

\section{HASIL DAN PEMBAHASAN}

\subsection{Hasil Penelitian}

a. Halaman Login Dashboard Admin dan Pakar

Halaman login Admin dan Pakar digunakan untuk masuk kedalam dashboard Pengelola Sistem dan Pakar. Pada halaman ini admin harus memasukan username dan password dengan benar kemudian klik tombol LOGIN untuk dapat masuk kedalam dashboard administrator.Desain dari halaman login dashboard admin dapat dilihat pada gambar 4

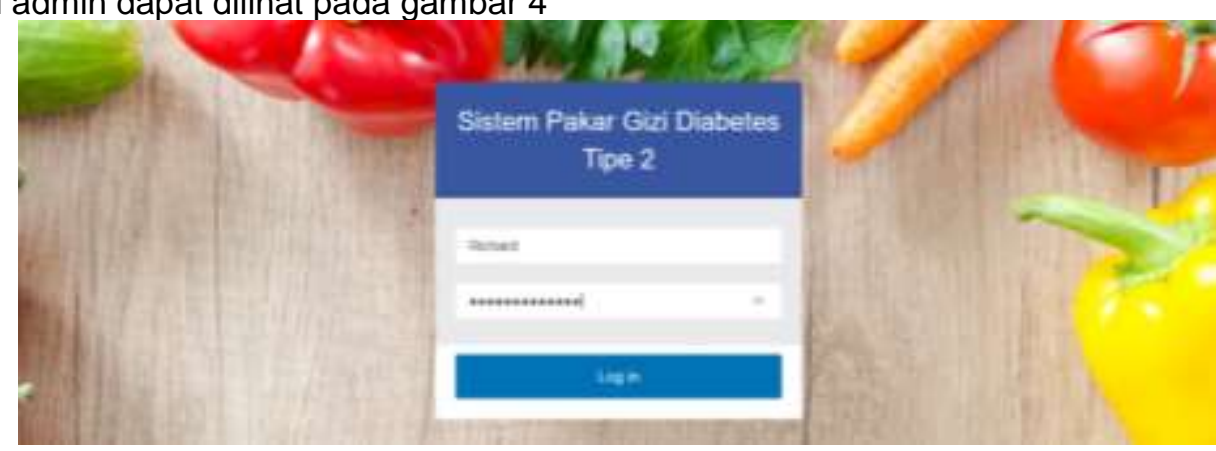

Gambar 4 Halaman Login Dashboard Admin dan Pakar 
b. Halaman Utama Pengelola Sistem

Halaman utama hanya dapat diakses oleh Admin yang dapat mengelola data-data tentang sistem pakar ini. Pada halaman ini menampilkan menu master pengguna, Berat Badan, Klasifikasi Umur, Pekerjaan, dan Makan, untuk dapat menuju ke halaman Master klik menupada dashboard admin. Tampilan dari halaman menu utama dapat dilihat pada gambar 5 .

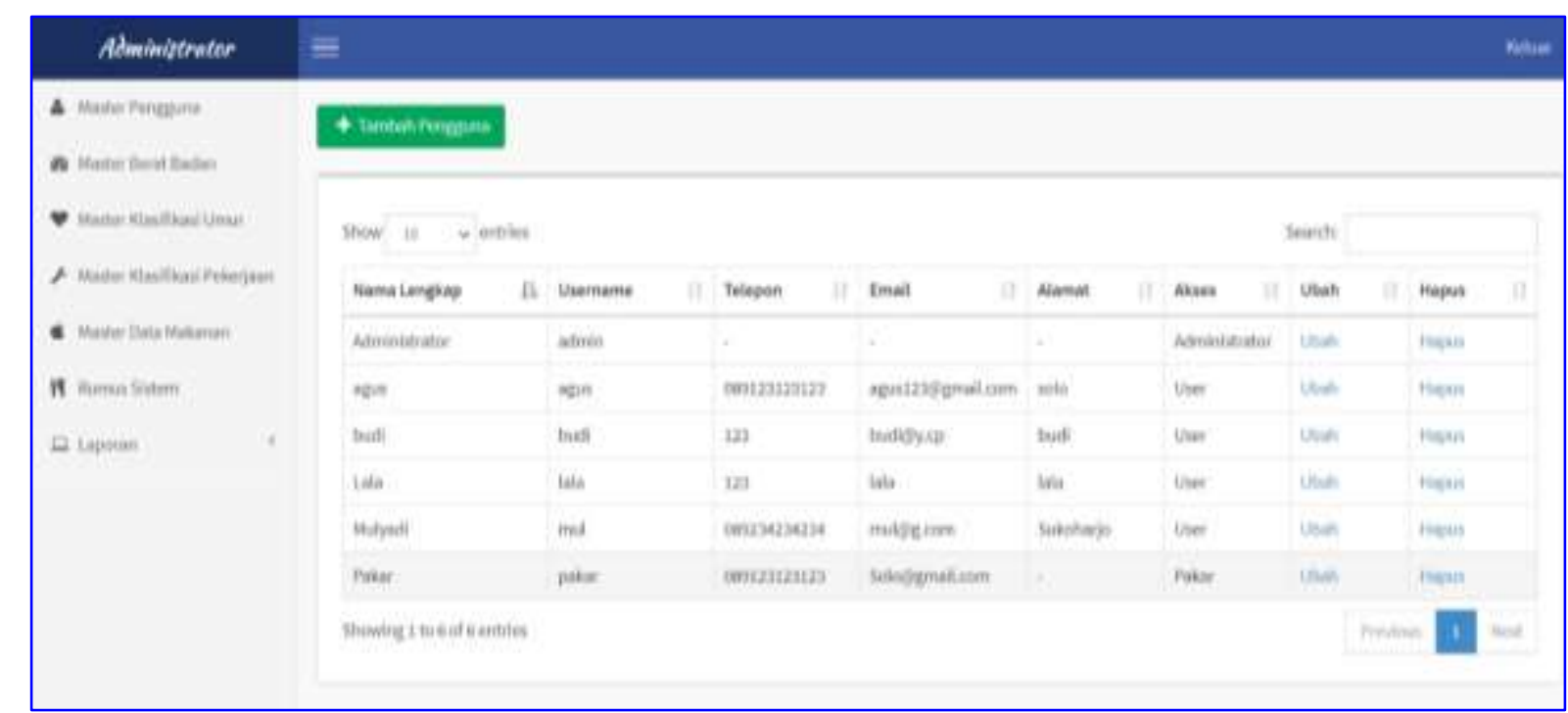

c. Halaman Utama Pakar Gizi

\section{Gambar 5 Halaman Pengelola Sistem}

Halaman menu utama Pakar Gizi dapat diakses setelah melakukan login pada dashboard admin. Pada halaman ini menampilkan menu utama dashboard pakar, menu-menu kepakaran dan informasi singkat mengenai dashboard pakar. Tampilan dari halaman menu utama dapat dilihat pada gambar 6 .

d. Halaman Utama Pengguna Sistem

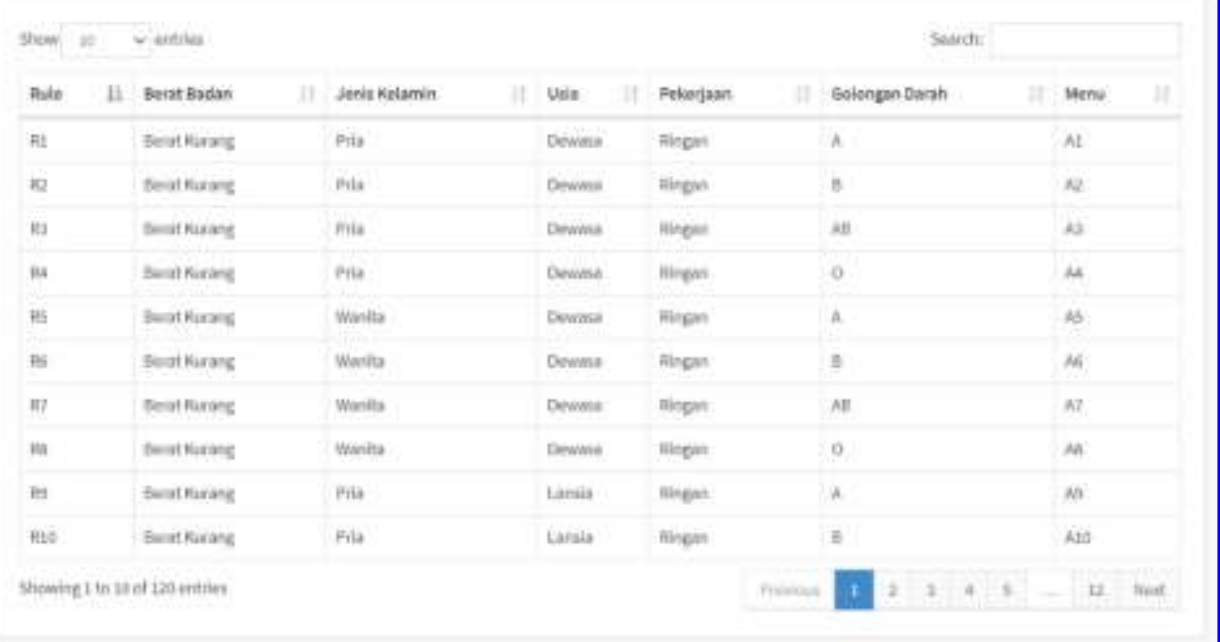

Gambar 6 Halaman Pakar Gizi

Pada saat membuka sistem ini pengguna pengguna diwajibkan melakukan Login terlebih dahulu setelah melakukan registrasi. Jika pengguna ingin Login klik tombol Login, dan jika registrasi Klik tombol Registrasi. Tampilan halaman utama ditunjukkan pada gambar 7 sebagai berikut: 


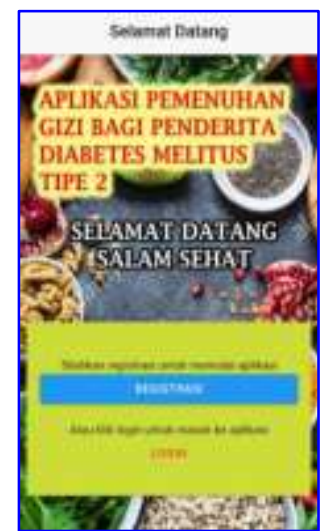

e. Halaman Registrasi Pengguna Sistem

Gambar 7 Halaman Utama Pengguna Sistem

Pengguna sistem dalam melakukan registrasi harus mengisikan data secara lengkap sesuai dengan form registrasi setelah selesai kemudian klik tombil Simpan pada gambar 8 dibawah ini

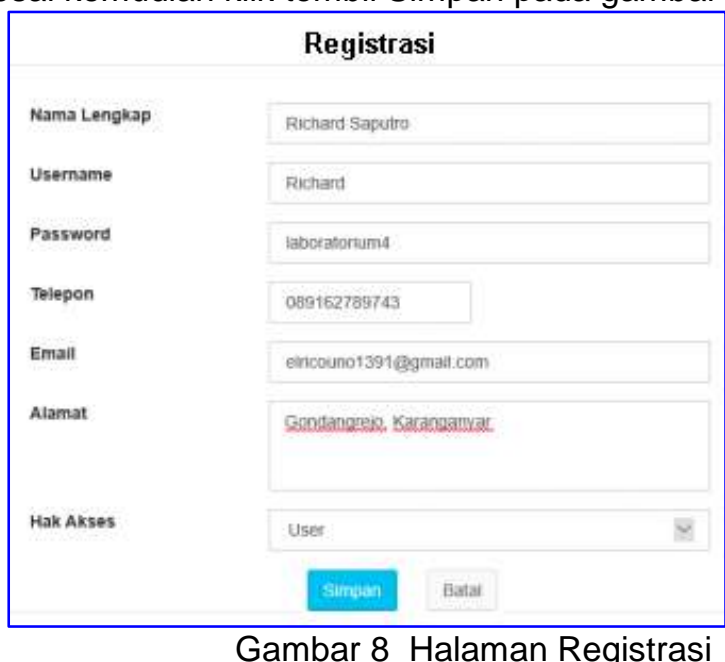

f. Halaman Login Pengguna Sistem

Gambar 8 Halaman Registrasi

Apabila pengguna sudah melakukan registrasi pada sistem ini, untuk dapat mengakses halaman selanjutkan klik Tombol Login, pada halaman Login pengguna harus memasukkan username dan pasword yang telah dibuat pada saat registrasi, halaman login dapat dilihat pada gambar 9 berikut ini.

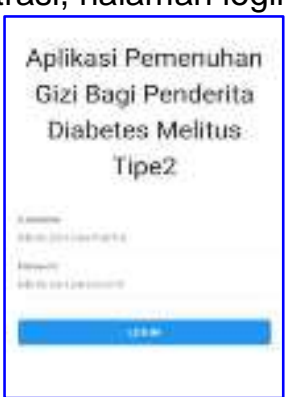

Gambar 9 Halaman Login Pengguna Sistem

g. Halaman Input Data Diri Pengguna

Pada halaman ini pengguna dapat memasukkan data diri pengguna seperti data Jenis Kelamin, Tanggal Lahir, Umur, Berat Badan, Tingi Badan, Golongan Darah dan Pekerjaan, setelah data selesai diinputkan kemudian klik tombol Simpan, seperti dapat dilihat pada gambar 10 


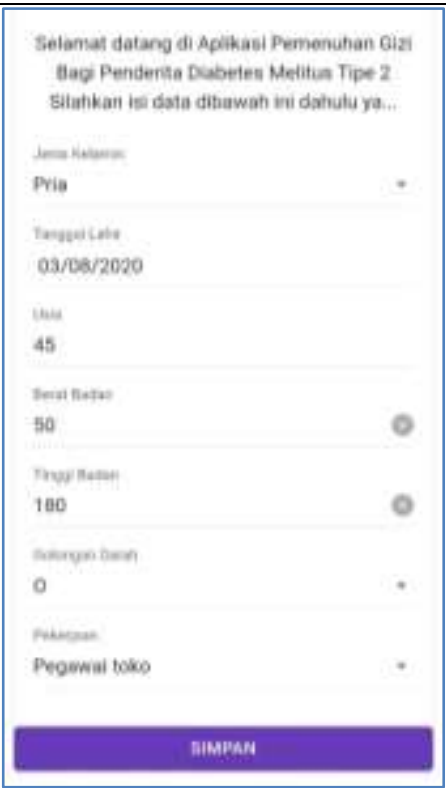

\section{Gambar 10 Halaman Layanan Konsultasi}

h. Halaman Layanan Konsultasi bagi Pengguna Sistem

Setelah pengguna sistem melakukan login maka dapat melakukan layanan konsultasi pada gambar 10 dibawah ini. Halaman ini menampilkan: (1) Tombol "Menu pagi, siang, malam" untuk memilih menu makanan berat yang ingin di konsumsi pengguna sistem dengan beberapa pilihan menu makanan. (2) Tombol "Menu Makanan Ringan" untuk memilih menu makanan ringan yang ingin di konsumsi pengguna sistem dengan beberapa pilihan menu makanan. (3) Kotak "konsultasi" untuk melakukan konsultasi dengan pakar gizi. (4) Kotak "Log out" untuk keluar dari sistem pakar

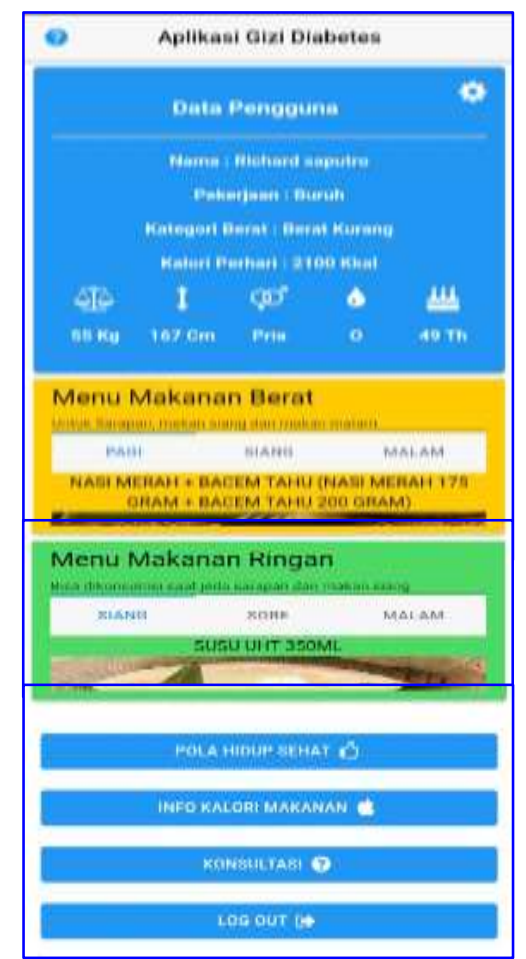

Gambar 11 Halaman Konsultasi Layanan Konsultasi

Setelah data diri dimasukkan seperti pada gambar 10, data tersebut diolah menggunakan metode Forward Chaining, kemudian hasilnya akan terlihat pada gambar 11, yang berisi informasi tentang:

i. Kebutuhan kalori perhari,

ii. Jenis menu makan berat pagi, siang dan malam yang dianjurkan untuk dikonsumsi,

iii. Jenis menu makanan ringan pagi, siang dan malam yang dianjurkan untuk dikonsumsi, 
iv. Informasi tentang pola hidup sehat,

v. Informasi tentang kalori makanan,

vi. Penguna dapat melakukan konsultasi melalui sistem pakar ini.

\subsection{Pembahasan}

Dalam pengembangan Sistem Pakar Pemenuhan Gizi Bagi Penderita Diabetes Melitus Tipe 2 Menggunakan Metode Forward Chaining Berbasis Android, penulis menggunakan analisis PIECES yang terdiri dari performance, information, control, efficiency, dan service untuk dapat mengetahui kemampuan sistem tersebu.t

a. Kinerja (Performance)

Pencarian tempat layanan menggunakan aplikasi, informasi yang diperoleh sangatlah cepat karena banyak layanan yang telah ditampilkan.

b. Informasi (Information)

Informasi yang diberikan sangat akurat karena informasi yang ditampilkan mencakup pemenuhan gizi.

c. Ekonomi (Economy)

Aplikasi disebarkan tanpa biaya jadi dapat diakses oleh banyak orang dan pengguna sistem tidak perlu membayar konsultasi dengan pakar gizi.

d. Pengendalian (Contro)

Informasi tempat layanan yang ditampilkan tidak diragukan karena sebelum perubahan data yang digunakan oleh pengguna sudah tervalidasi terlebih dahulu oleh pakar gizi melalui konfirmasi dari pengelola sistem.

e. Efisiensi (Efficiency)

Semua pengguna aplikasi tidak perlu ke tempat pakar gizi atau pakar diabetes untuk berkonsultasi, karena sudah terdapat layanan konsultasi online dengan pakar gizi di sistem ini.

f. Layanan (Service)

Informasi yang ditampilkan berupa menu makanan bergizi, anjuran pola hidup sehat dan kolom konsultasi untuk memudahkan pengguna dalam memahami dan mengaplikasikan anjuran dalam sistem.

\subsection{Pengujian Sistem}

Pengujian pada Sistem Pakar Pemenuhan Gizi Diabetes Melitus Tipe 2 dilakukan menggunakan metode black box yaitu pengujian yang berfokus pada fungsi-fungsi sub sistem sistem dibuat. Pengujian black box ini berfokus pada kesalahan yang terjadi dalam fungsi yang tidak benar misalnya kesalahan interface, input dan output serta pada struktur data. Pengujian selengkapnya dapat terlihat pada tabel di bawah ini:

Tabel 1 Pengujian Sistem Pakar menggunakan metode Black Box

\begin{tabular}{|c|c|c|c|c|}
\hline $\begin{array}{c}\text { Form yang } \\
\text { Diuji }\end{array}$ & Data Masukkan & Yang Diharapkan & Pengamatan & Hasil \\
\hline $\begin{array}{l}\text { Login } \\
\text { Dashboard } \\
\text { Admin }\end{array}$ & $\begin{array}{l}\text { Username dan } \\
\text { password yang } \\
\text { benar }\end{array}$ & $\begin{array}{l}\text { Dapat masuk ke halaman } \\
\text { menu utama }\end{array}$ & Berhasil Login & $\begin{array}{l}\text { [ }] \text { ] Diterima } \\
\text { [ ] Ditolak }\end{array}$ \\
\hline $\begin{array}{l}\text { Login } \\
\text { Pengguna }\end{array}$ & $\begin{array}{l}\text { Username dan } \\
\text { password } \\
\text { pengguna }\end{array}$ & $\begin{array}{l}\text { Dapat masuk ke halaman } \\
\text { utama aplikasi android } \\
\text { pemenuhan gizi bagi } \\
\text { Diabetes Mellitus tipe } 2\end{array}$ & Berhasil login & $\begin{array}{l}\text { [V] Diterima } \\
\text { [ ] Ditolak }\end{array}$ \\
\hline $\begin{array}{l}\text { Pelayanan } \\
\text { menu } \\
\text { makan }\end{array}$ & $\begin{array}{l}\text { Klik menu } \\
\text { makanan }\end{array}$ & $\begin{array}{l}\text { Dapat menampilkan } \\
\text { daftar menu makanan } \\
\text { yang sudah divalidasi } \\
\text { oleh pakar gizi, mencetak } \\
\text { nota dan memasukan } \\
\text { nomor resi pengiriman }\end{array}$ & $\begin{array}{l}\text { Menampilkan daftar } \\
\text { menu makanan }\end{array}$ & $\begin{array}{l}\text { [ }] \text { ] Diterima } \\
\text { [ ] Ditolak }\end{array}$ \\
\hline Laporan & Klik menu lapoan & $\begin{array}{l}\text { Dapat mencetak laporan } \\
\text { Layanan }\end{array}$ & $\begin{array}{l}\text { Menampilkan } \\
\text { cetakan laporan } \\
\text { Layanan }\end{array}$ & $\begin{array}{l}{[\sqrt{ }] \text { Diterima }} \\
\text { [ ] Ditolak }\end{array}$ \\
\hline $\begin{array}{l}\text { Registrasi } \\
\text { user / } \\
\text { pengguna }\end{array}$ & $\begin{array}{l}\text { Data lengkap } \\
\text { pengguna }\end{array}$ & $\begin{array}{l}\text { Menampilkan form } \\
\text { registrasi pengguna untuk } \\
\text { digunakan login ke dalam } \\
\text { sistem }\end{array}$ & $\begin{array}{l}\text { Menampilkan form } \\
\text { registrasi }\end{array}$ & $\begin{array}{l}\text { [ل] Diterima } \\
\text { [ ] Ditolak }\end{array}$ \\
\hline $\begin{array}{l}\text { Login } \\
\text { aplikasi } \\
\text { android }\end{array}$ & $\begin{array}{l}\text { Username dan } \\
\text { password } \\
\text { pengguna }\end{array}$ & $\begin{array}{l}\text { Dapat masuk ke halaman } \\
\text { utama sistem android } \\
\text { pemenuhan gizi bagi } \\
\text { Diabetes Mellitus tipe } 2\end{array}$ & Berhasil login & $\begin{array}{l}{[\sqrt{ }] \text { Diterima }} \\
\text { [ ] Ditolak }\end{array}$ \\
\hline
\end{tabular}




\section{KESIMPULAN}

Sistem Pakar Pemenuhan Gizi Bagi Penderita Diabetes Melitus Tipe 2 Menggunakan Metode Forward Chaining Berbasis Android sudah diuji dan diimplementasikan. Sistem ini dapat memberikan informasi menu makanan bergizi, pola makan dan hidup sehat serta konsultasi dengan pakar gizi terkait tentang diabetes mellitus tipe 2. Sistem Pakar Pemenuhan Gizi Bagi Penderita Diabetes Melitus Tipe 2 Menggunakan Metode Forward Chaining Berbasis Android dalam analisa sistem menggunakan Analisa PIECES serta perancangan menggunakan pemodelan Flowchart dan UML (Unified Modeling Language) dengan komponen yang digunakan yaitu usecase diagram, activity diagram, sequence diagram, dan desain interface. Sistem Pakar dibangun menggunakan bahasa pemrograman Java dengan Apache Cordova dan database menggunakan MySQL. Sehingga menghasilkan Sistem Pakar Pemenuhan Gizi Bagi Penderita Diabetes Melitus Tipe 2 Menggunakan Metode Forward Chaining Berbasis Android yang berhasil diimplementasikan di dalam aplikasi ini untuk mempermudah penyampaian informasi menu makanan bergizi, pola makan dan hidup sehat serta konsultasi dengan pakar gizi terkait tentang diabetes mellitus tipe 2.

\section{REFERENSI}

Almatsier, S. 2007. Prinsip Dasar IImu Gizi. Jakarta: Gramedia Pustaka Utama.

Alfata, Hanif Al. 2007. Analisis dan Perancangan Sistem Informasi. Yogyakarta: Andi.

Andi, dan Komputer, W. 2015. Panduan Aplikatif \& Splusi (PAS): Membangun Sistem Informasi dengan Java NetBeans dan MySQL. Yogyakarta:Andi Offset.

Blanco, J.A. and Upton, D. 2009. Codeigniter 1.7. Packt Publishing.

Connolly, Thomas and Bagg, Charolyn. 2010. Database system A practicial approach to design, Implementation and Management Fifth Edition, Boston: Pearson Education.

Candra, Suriyanti. 2014. Sistem Pakar Penentuan Menu Makanan Sehat Penderita Diabetes Mellitus Berbasis Mobile.

D’Adamo, Peter J.dan Whitney, Chaterine. 2006. Diet Sehat Golongan Darah O. Jakarta, Buana IImu Populer.

D'Adamo, Peter J.dan Whitney, Chaterine. 2006. Diet Sehat Golongan Darah A. Delapratasa Publishing.

DeCoster. 2012. Pengertian Java Development Kit. http://library.binus.ac.id, diakses pada tanggal 21 November 2017.

Deitel, H. M. 2012. Java Script Education Person, Programing Module of Netherland vol 34. Indonesia Language.

Dinas Kesehatan Kota Surakarta. 2017. Profil Kesehatan Kota Surakarta Tahun 2017. Surakarta : DKK Surakarta.

Fathansyah. 2002. Basis Data. Bandung: Informatika.

Hermawan S, Stephanus. 2011."Mudah Membuat Aplikasi Android". Yogyakarta : Andi Offset.

Halls, Steven B. 2005. Ideal weight formulas by Broca and Devine. Canada.

International Diabetes Federation. 2015. IDF Diabetes Atlas. International Diabetes Federation. https://doi.org/10.1289/image.ehp.v119.i03.

Juhara, Zamrony P. 2016. "Panduan Lengkap Pemrogaman Andorid". Yogyakarta : Andi Offset.

Kristanto, Andri. 2003, Perancangan Sistem Informasi dan Aplikasinya, Penerbit :Gava Media, Jakarta.

Lusiana, T. dan Qoiriah, A. 2014. Sistem Pakar untuk Menentukan Menu Makanan Sehat pada Penderita Diabetes Mellitus. STIKOM Surabaya. Surabaya

Nugroho. 2013. Mengenal XAMPP Awal. Yogyakarta: MediaKom.

Pressman, Roger, S. 2001. Software Engineering: A Practitioner's Approach, Fifth Ed. New York, McGrawHill Book Company.

Rifki I. P. 2014. Purwarupa Sistem Pakar Untuk Menentukan Jumlah Kalori Diet Bagi Penderita Diabetes Mellitus. UPN "Veteran" Yogyakarta. Yogyakarta.

Rismawan, T. dan Kusumadewi, S. 2008. Aplikasi K-Means untuk Pengelompokan Mahasiswa Berdasarkan Body Mass Index (BMI) \& Ukuran Kerangka. Seminar Nasional Aplikasi Teknologi Informasi 2008 (SNATI 2008). Yogyakarta.

Rosa AS dan M.Shalahuddin. 2014. Rekayasa Perangkat Lunak Terstruktur Dan Berorientasi Objek. Bandung : INFORMATIKA.

Rudianto, Arief M. 2011. Pemrograman Web Dinamis menggunakan PHP dan MYSQL. Yogyakarta: ANDI OFFSET.

Safaat, Nazrudi. 2012. Android Pemrograman Aplikasi Mobile Smartphone dan Tablet PC Berbasis Android.Bandung:Informastika.

Slitonga, J. dkk. 2013. Pendaftaran Mahasiswa Baru Berbasis Mobile. Universitas Maritim Raja Ali Haji. Kepulauan Riau.

Svennerberg, G. 2010. Begining Google Maps Api 3. New York : Apress. 